\title{
Cholecalciferol therapy; is it the gold standard for vitamin D deficiency and mineral disorders in hemodialysis?
}

\author{
Mouna Jerbi ${ }^{*}$, Hiba Ghabi ${ }^{2}$, Hanene Gaied ${ }^{2}$, Fathi Ben Hmida ${ }^{3}$, Raja Aoudia ${ }^{3}$, Rim Goucha ${ }^{1}$, Taieb Ben \\ Abdallah $^{3}$
}

\begin{abstract}
Introduction: Vitamin D deficiency is frequently observed among dialysis patients. Previous studies suggested that 50 to $90 \%$ of end-stage renal disease patients are deficient in vitamin D. In Tunisia, studies regarding hypovitaminosis D in patients on dialysis are not numerous. Actually, many data support the use of native vitamin D in hemodialysis (HD) patients. In Tunisia, using native vitamin D is not part of therapeutic habits of all dialysis centers.

Objectives: The aim of this study was to determine the prevalence of vitamin D deficiency in patients with chronic kidney disease stage 5 undergoing $\mathrm{HD}$ and to evaluate the effect of oral cholecalciferol supplementation, in intact parathormone (iPTH), serum calcium and serum phosphorus.

Patients and Methods: We conducted a pre-experimental study among HD patients. Monthly oral supplementation with Cholecalciferol, was instituted for six months.

Results: Forty-three participants were included. The mean 25-hydroxy vitamin D concentration was $17.89 \mathrm{ng} / \mathrm{mL}$. Vitamin D deficiency was observed in $83.7 \%$ of our patients. We observed a significant increase in 25 -hydroxy vitamin D and calcium levels and a significant decline in iPTH levels. No evidence of toxicity, nor severe hypercalcemia or hyperphosphatemia was noted.

Conclusion: The supplementation with cholecalciferol seems reasonable and well tolerated in HD patients if reasonable doses are used with regular monitoring.

Keywords: Vitamin D, Hemodialysis, Chronic kidney disease, Hemodialysis, Parathormone, End-stage renal disease

Citation: Jerbi M, Ghabi H, Gaied H, Ben Hmida F, Aoudia R, Goucha R, Ben Abdallah T. Cholecalciferol therapy; is it the gold standard for vitamin D deficiency and mineral disorders in hemodialysis? J Renal Endocrinol. 2021;7:e09. doi: 10.34172/jre.2021.09.

Copyright $\odot 2021$ The Author(s); Published by Nickan Research Institute. This is an open-access article distributed under the terms of the Creative Commons Attribution License (http://creativecommons.org/licenses/by/4.0), which permits unrestricted use, distribution, and reproduction in any medium, provided the original work is properly cited.
\end{abstract}

\section{Introduction}

Vitamin D deficiency is frequently observed among hemodialysis (HD) patients. Previous studies suggest that $50 \%$ to $90 \%$ of end-stage renal disease (ESRD) patients are deficient in vitamin D (1). Significant evidence has been accumulated these recent years supporting the benefit of using vitamin D in HD patients. In fact, vitamin D deficiency has been associated with secondary hyperparathyroidism (SHPT) (2), since serum 25-hydroxyvitamin D $(25(\mathrm{OH})$ D) levels should be maintained above $30 \mathrm{ng} / \mathrm{mL}$ in order to prevent parathyroid hormone $(\mathrm{PTH})$ from increasing (3).

Its correction is relatively easy and well detected in a subject with normal renal function. Unfortunately in patients with chronic kidney disease (CKD), especially HD patients, the correction is not yet well codified due to the lack of prospective studies.

To be active, vitamin $\mathrm{D}$ must benefit from a double hydroxylation; the first hydroxylation, is carried out by the liver and the second is carried out under the action of 1-alpha-hydroxylase, mainly at the level of the proximal convoluted tubule to form calcitriol (4).

CKD is associated with loss of renal 1 a hydroxylase activity. Classically, nephrologists use active vitamin $\mathrm{D}$ to compensate this deficit. Both the Kidney Disease Outcomes Quality Initiative (KDOQI) and Kidney Disease Improving Global Outcomes (KDIGO) experts recommend checking and supplementing low serum $25(\mathrm{OH}) \mathrm{D}$ levels in $\mathrm{CKD}$ and $\mathrm{HD}$ patients $(5,6)$ why active vitamin $\mathrm{D}$ is usually administered.

Over the last fifteen years, many scientific advances have profoundly changed the understanding of the vitamin D physiology, the co-expression of vitamin D receptors with 1-a-hydroxylase, in many peripheral tissues, has come to light a new concept, while the active form of vitamin $\mathrm{D}$, the $1.25(\mathrm{OH}) \mathrm{D} 3$, can be synthesized in extrarenal sites and

'Department of Nephrology, Mongi Slim Hospital, Marsa, Laboratory of Kidney Pathology (LR00SP01) Charles Nicolle Hospital, Faculty of Medicine Tunis, University of Tunis El Manar, Tunis, Tunisia. ${ }^{2}$ La Rabta Hospital, Department of Nephrology, Faculty of Medicine Tunis, University of Tunis El Manar, Tunis, Tunisia. ${ }^{3}$ Department of Nephrology, Charles Nicolle Hospital, Laboratory of Kidney Pathology (LR00SP01) Charles Nicolle Hospital, Faculty of Medicine, University of Tunis El Manar, Tunis, Tunisia.

*Corresponding Author: Mouna Jerbi, Email: mounaeleuch@outlook.fr 


\section{Implication for health policy/practice/research/ medical education}

In a pre-experimental study on HD patients, we found vitamin D supplementation using cholecalciferol $(800000$ UI during 6 months) was associated with significant increase in serum $25 \mathrm{OH}$ vitamin $\mathrm{D}$ and calcium and a significant decline in intact parathormone (iPTH) serum levels. No evident toxicity, nor severe hypercalcemia or increase in phosphorus level was noted.

generate local autocrine effects $(7,8)$. Actually many data support the use of native vitamin D in HD patients (9). There has been renewed interest in studying the effects of supplementation with native vitamin $\mathrm{D}$ (cholecalciferol) in CKD patients with low 25(OH) D levels $(10,11)$. Likewise, this interest has been shown by the studies that have demonstrated several potential non-skeletal benefits of vitamin D. These benefits include effect of vitamin D on immune system, cardiovascular disease, diabetes, and some cancers $(12,13)$.

In Tunisia, studies regarding hypovitaminosis $\mathrm{D}$ in patients with CKD stage 5 on dialysis are not numerous and using native vitamin $\mathrm{D}$ is not part of therapeutic habits of all dialysis centers.

\section{Objectives}

In the present study, we examined the prevalence of vitamin $\mathrm{D}$ deficiency in patients with CKD stage 5 undergoing HD and evaluated the effect of oral cholecalciferol supplementation, in intact parathyroid hormone (iPTH), serum calcium $(\mathrm{Ca})$ and serum phosphorus in this population.

\section{Materials and Methods}

This was a pre-experimental study conducted in HD department of Charles Nicolle hospital during six months. All measurements were carried out at the biochemistry laboratory of the hospital.

We included patients of CKD stage 5 who were on maintenance $\mathrm{HD}$ for more than one year. They were adults (age $>18$ years). Patients were not included if they had a history of active vitamin D or calcimimetic treatment in the last year, parathyroidectomy, iPTH $<300$ $\mathrm{pg} / \mathrm{mL}$, hepatic failure or digestive malabsorption. Those with serum calcium greater than $2.55 \mathrm{mmol} / \mathrm{L}$ or serum phosphorus greater than $2 \mathrm{mmol} / \mathrm{L}$ were not included. The calcium concentration during HD sessions was set at $1.5 \mathrm{mmol}$ for all patients. Informed consent was required for all patients.

25(OH) vitamin D serum levels, intact PTH (iPTH), as well as serum calcium and phosphorus were analyzed in fasting samples before and 15 days after the end of treatment. Blood samples for $25(\mathrm{OH})$ vitamin D levels were obtained before dialysis. Serum $25(\mathrm{OH})$ vitamin $\mathrm{D}$ levels were measured using a commercially available radioimmunoassay. Intact $\mathrm{PTH}$ was determined by an automated chemiluminescence immunoassay. Serum calcium and phosphorus were measured by standard laboratory methods.

In this study, we considered adequate vitamin D levels those above $30 \mathrm{ng} / \mathrm{mL}$ (US National Kidney Foundation DOQI guidelines), vitamin $\mathrm{D}$ insufficiency when levels were between 20 and $30 \mathrm{ng} / \mathrm{mL}$, vitamin $\mathrm{D}$ moderate deficiency when levels were between 10 and $20 \mathrm{ng} / \mathrm{mL}$ and severe deficiency when levels were below $10 \mathrm{ng} / \mathrm{mL}$.

Monthly oral supplementation with cholecalciferol (200000 UI), was then instituted for six months (M1, M2, M4 and M6) totaling 800000 UI. For better compliance cholecalciferol was given in the morning on empty the day of non-HD.

The response to treatment was evaluated as follows;

- Partial response if $25(\mathrm{OH})$ vitamin D level is $<30 \mathrm{ng} /$ $\mathrm{mL}$ at M6.

- Adequate response if $25(\mathrm{OH})$ vitamin $\mathrm{D}$ level is between $30 \mathrm{ng} / \mathrm{mL}$ and $60 \mathrm{ng} / \mathrm{mL}$ at $\mathrm{M} 6$.

- $\quad$ Excessive response if $25(\mathrm{OH})$ vitamin D level is $>60$ $\mathrm{ng} / \mathrm{mL}$ at $\mathrm{M} 6$.

For all statistical analyses, $P$ value $\leq 0.05$ was considered to be significant. All statistical analyses were performed with Statistica software. We used a paired sample $t$ test to compare means of quantitative variables before and after supplementation.

Results

Forty-three Caucasian participants were included in the study. Mean age was 51.3 years. Of these, 18 were females and 25 were males. Median duration of dialysis was 6.5 years (range $1-19$ years). Six (13.9\%) patients had diabetic nephropathy.

We found that $83.7 \%$ of our patients had vitamin D insufficiency or deficiency (a serum 25-OH vitamin D level below $30 \mathrm{ng} / \mathrm{mL})(\mathrm{n}=36)$. Before treatment, the mean $25(\mathrm{OH}) \mathrm{D}$ was $17.89 \mathrm{ng} / \mathrm{mL}[6-57.3 \mathrm{ng} / \mathrm{mL}]$ (Table 1).

Changes in vitamin $D$, calcium, phosphorus and $i P T H$, after cholecalciferol supplementation

The cholecalciferol supplementation allowed a significant increase of $25(\mathrm{OH})$ vitamin D levels (from $17.89 \mathrm{ng} /$ $\mathrm{mL}$ to $51.8 \mathrm{ng} / \mathrm{mL}$ ). The average plasma concentration of calcium has significantly increased between $\mathrm{M} 0$ and M6, 2.05 (M0) versus $2.15 \mathrm{mmol} / \mathrm{L}$ (M6). No episode of hypercalcemia was noted.

Basal iPTH concentration observed before vitamin D

Table 1. Biomedical characteristics before treatment

\begin{tabular}{ll}
\hline Vitamin D (ng/mL) & $17.89(6-57.3)$ \\
PTH $(\mathbf{p g} / \mathbf{m L})$ & $956 \pm 413.24$ \\
Phosphorus (mmol/L) & $1.56 \pm 0.27$ \\
Calcium (mmol/L) & $2.05 \pm 0.24$ \\
\hline
\end{tabular}


supplementation was $956 \mathrm{pg} / \mathrm{mL}$. After treatment, the mean concentration decreased significantly. Overall, iPTH concentration decreased from $956 \mathrm{pg} / \mathrm{mL}$ to $699 \mathrm{pg} /$ $\mathrm{mL}$ between $\mathrm{M} 0$ and $\mathrm{M} 6$.

The average serum phosphorus level progress was not significant: $1.56 \mathrm{mmol} / \mathrm{L}$ at $\mathrm{M} 0$, to $1.49 \mathrm{mmol} / \mathrm{L}$ at $\mathrm{M} 6$. These values remain lower than the upper limit (1.78 $\mathrm{mmol} / \mathrm{L}$ ) according to the K/DOQI recommendations (Table 2).

The increase of serum $25(\mathrm{OH})$ vitamin D level was conditioned by initial concentrations of $25(\mathrm{OH})$ vitamin D (Table 3).

\section{Discussion}

Our study confirms the high prevalence of the $25(\mathrm{OH})$ vitamin $\mathrm{D}$ deficiency in $\mathrm{HD}$ patients, with a mean 25 $(\mathrm{OH})$ vitamin D concentration of $17.89 \mathrm{ng} / \mathrm{mL}$. Vitamin $\mathrm{D}$ deficiency was observed in $83.7 \%$ of our patients.

Referring to the concentrations recommended by the American Nephrology Society, only $16.3 \%$ of our patients reach desirable concentrations of $25(\mathrm{OH})$ vitamin $\mathrm{D}>30$ $\mathrm{ng} / \mathrm{mL}$ (3).

At the dialysis stage, the deficit in vitamin D affects 53.5 to $89 \%$ of HD (1). In Asian countries, studies have shown a high prevalence of vitamin D deficiency. The study of Hashemipour et al reported that $81.3 \%$ subjects had a decline in vitamin $\mathrm{D}$ reserves with a prevalence of vitamin $\mathrm{D}$ deficiency between $30 \%$ and 93\% (14). Recently, a French team reported vitamin D insufficiency with serum $25(\mathrm{OH})$ vitamin $\mathrm{D}$ level $<30 \mathrm{ng} / \mathrm{mL}$ in $72 \%$ of their $\mathrm{HD}$ patients (15). In Africa, data on dialysis are not numerous. In Nigeria, a study reports a deficit in $1,25(\mathrm{OH}) 2 \mathrm{D}$ in $83.3 \%$ of patients (16). In Tunisia, a cumulative prevalence of vitamin D deficiency of $47.6 \%$ was reported in healthy population (17). In a study conducted in southern Tunisia involving 63 dialysis patients (HD, peritoneal dialysis), the average level of $25(\mathrm{OH})$ vitamin $\mathrm{D}$ was $10.5 \pm 9.13 \mathrm{ng} / \mathrm{mL}$.

Table 2. Changes in vitamin D, calcium, phosphorus and PTH, after cholecalciferol supplementation

\begin{tabular}{lccc}
\hline & Pre-supplementation & Post-supplementation & $\boldsymbol{P}$ value \\
\hline $\begin{array}{l}\text { Vitamin D } \\
(\mathrm{ng} / \mathrm{mL})\end{array}$ & 17.89 & 51.8 & $<0.001$ \\
$\mathrm{Ca}(\mathrm{mmol} / \mathrm{L})$ & 2.05 & 2.15 & 0.014 \\
$\begin{array}{l}\text { Phosphorus } \\
(\mathrm{mmol} / \mathrm{L})\end{array}$ & 1.56 & 1.49 & 0.78 \\
$\mathrm{PTH}(\mathrm{pg} / \mathrm{mL})$ & 956 & 699 & $<0.001$ \\
\hline
\end{tabular}

Serum $25 \mathrm{OH}$ vitamin $\mathrm{D}$ level $<15 \mathrm{ng} / \mathrm{mL}$ was shown in $41.3 \%$ of patients and between 15 and $30 \mathrm{ng} / \mathrm{mL}$ in $50.8 \%$ of patients (18).

Vitamin $\mathrm{D}$ is a hormonal system involved in the regulation of hundreds of genes and metabolisms by the local or endocrine production of $1,25-\mathrm{OH} 2$ vitamin $\mathrm{D}$ with a primary effect on cellular differentiation and proliferation (19). Vitamin D deficiencyhas been associated with the risk of cancer (20) diabetes (13), autoimmune and cardiovascular diseases, osteoporosis, musculoskeletal function impairment, and neuropsychiatric disorders (12). Therefore, it has an important role in the prevention of diabetes, different types of cancer, autoimmune diseases, and in the defense against tuberculosis (21).

In the general population, the optimal serum $25(\mathrm{OH})$ vitamin $\mathrm{D}$ level is not known, but it is thought to be above $30 \mathrm{ng} / \mathrm{mL}$ (22).

This deficiency is due to a restrictive diet in vitamin $\mathrm{D}$, as well as low exposure to sunlight, which leads to a decrease in the cutaneous synthesis of vitamin D. In our study, all female population was veiled women with a low-sunlight exposure. In addition, chronic HD patients have decreased photoproduction of cholecalciferol, despite a normal epidermal content of the substrate, 7 -dehydrocholesterol (23). A study suggests a decrease in hepatic 25-hydroxylase activity related to uremia too (24).

Vitamin D deficiency among dialysis patients has become an increasingly important problem for nephrologists in the last 10 years. In fact, end-stage renal disease is associated with a decrease in vitamin $\mathrm{D}$ activity by mechanism including the increase of plasma phosphate concentration, secretion of fibroblast growth factor-23 and decrease in 1 alpha hydroxylase activity. Currently is well established that a patient has to be substituted when $25 \mathrm{OH}$ vitamin D level is less than $30 \mathrm{ng} / \mathrm{mL}$. The goals of vitamin D treatment in case of ESRD are to substitute the deficiency and to prevent or treat hyperparathyroidism. Lowering excessive serum PTH levels have many beneficial effects by increasing myocardial contractility, decreasing myocardial fibrosis and vascular calcification, increasing immune function, insulin sensitivity, and erythropoiesis. But the beneficial effects of vitamin D may also involve a direct action on hypertension, cardiac hypertrophy, tumorigenesis, immunologic function, atherosclerosis, and thrombosis (25). With the Kidney Disease: Improving Global Outcomes 2016 recommendation being recently released, it is hypothesized that nephrologists will

Table 3. Changes in the $25(\mathrm{OH}) \mathrm{D}$ after cholecalciferol treatment according to the baseline vitamin D level

\begin{tabular}{lccc}
\hline Baseline vitamin D level $(\mathbf{n g} / \mathbf{m L})$ & $\begin{array}{c}\text { Partial response }(\text { Vit } \mathbf{D}<\mathbf{3 0} \\
\mathbf{n g} / \mathbf{m L})\end{array}$ & $\begin{array}{c}\text { Adequate response }(\text { Vit } \mathbf{D} \text { between } \mathbf{3 0} \text { and } \\
\mathbf{6 0} \mathbf{~ n g} / \mathbf{m L})\end{array}$ & $\begin{array}{c}\text { Excessive response } \\
(\mathbf{V i t} \mathbf{D}>\mathbf{6 0} \mathbf{~ n g} / \mathbf{m L})\end{array}$ \\
\hline$<10$ & $54.5 \%$ & $45.5 \%$ & 0 \\
$10-20$ & $46.2 \%$ & $46.2 \%$ & $7.6 \%$ \\
$20-30$ & $0 \%$ & $62.5 \%$ & $37.5 \%$ \\
\hline
\end{tabular}


implement a strategy for $25(\mathrm{OH})$ vitamin $\mathrm{D}$ deficiency checking and supplementation more systematically (5).

However, the more appropriate vitamin D compounds for HD patients remain an unavoidable subject. The controversy about active vitamin $\mathrm{D}$ and native vitamin $\mathrm{D}$ heats up.

Past studies have recommended the use of native vitamin $\mathrm{D}$ in HD patients. As knowledge improves, this use then fell somewhat into disuse; especially for the benefit of active vitamin D. Actually, native vitamin D has regained an important place in our arsenal therapy. In a descriptive study conducted in 2011 in the Sahel of Tunisia involving $50 \mathrm{HD}$ patients belonging to the same center, $38 \%$ of them were treated by active vitamin D versus $50 \%$ using native vitamin D (26).

In our study, vitamin D supplementation using cholecalciferol (800000 UI during 6 months) was associated with significant increase in serum $25(\mathrm{OH})$ vitamin $\mathrm{D}$ and calcium and a significant decline in $\mathrm{PTH}$ serum levels. No evident toxicity, nor severe hypercalcemia or increase in phosphorus level was noted.

Several studies have assessed the effect of native vitamin $\mathrm{D}$ on mineral parameters in HD patients. We will compare our results to the studies that used cholecalciferol in HD patients. We have deliberately omitted studies that have used other native vitamin D.

Indeed, several scientific data suggest that these forms do not have the same bioavailability (23).

A significant improvement in $25 \mathrm{OH}$ vitamin $\mathrm{D}$ level after cholecalciferol supplementations was reported by all previous studies. Jean et al observed a significant improvement of $25(\mathrm{OH})$ vitamin D levels (from $13 \pm 5 \mathrm{ng}$ / $\mathrm{mL}$ to $42 \pm 11 \mathrm{ng} / \mathrm{mL}$ ) in one cohort of $107 \mathrm{HD}$ patients after 15 months of monthly doses of cholecalciferol. Serum PTH levels also decreased significantly (median 295-190 $\mathrm{pg} / \mathrm{mL}, P<0.001)$. No significant changes were observed in the values of serum calcium and phosphate (15). Matias et al reported (11), a significant increase in $25 \mathrm{OH}$ vitamin D levels (from $22 \pm 12 \mathrm{ng} / \mathrm{mL}$ to $42 \pm 12 \mathrm{ng} / \mathrm{mL}$ ) in one study of $158 \mathrm{HD}$ patients receiving cholecalciferol treatment. Conversely, serum calcium, phosphorus, and iPTH were decreased (11). In 2013, Delanay et al (29) reported a decrease of PTH levels from 312 to $175 \mathrm{pg} /$ $\mathrm{mL}$ after cholecalciferol treatment for one year but it was a small patient number. In 2018, Tunisian authors compared the effect of cholecalciferol versus ergocalciferol on mineral discords in HD patients and reported a significant increase of vitamin $\mathrm{D}$ levels and a significant decrease of PTH levels with cholecalciferol. We specify that these patients have already received ergocalciferol for three months before cholecalciferol which could represent a bias of the study (30).

However, many studies reported that cholecalciferol treatment had an effect on only $25(\mathrm{OH})$ vitamin D levels and did not change either calcium, phosphorus or $\mathrm{PTH}$ values (31-36).
The question that arises now is why there is disparity from results especially regarding changes in iPTH levels after cholecalciferol treatment?

This disparity can be explained by several reasons. First, in some previous studies reporting the effect of cholecalciferol supplementation, patients receiving therapy influencing calcium metabolism were not excluded. Some authors included patients having parathyroidectomy. Thus the effect of $25(\mathrm{OH})$ vitamin D on parathyroid is less than expected. Secondly, this disparity can be explained by the variability of bioavailable $25(\mathrm{OH})$ vitamin $\mathrm{D}$ level between the Tunisian population and others. Bioavailable vitamin $\mathrm{D}$ is the free portion of $25(\mathrm{OH})$ vitamin $\mathrm{D}$ not bound to vitamin D binding protein (DBP). This is the only active fraction responsible for the biological effects of $25(\mathrm{OH})$ vitamin $\mathrm{D}$ (Table 4 ).

Prior studies demonstrated that bioavailable vitamin $\mathrm{D}$ but not $25(\mathrm{OH}) \mathrm{D}$ and $1,25(\mathrm{OH})$ vitamin $\mathrm{D}$ is significantly associated with iPTH and calcium level (37-39). The free $25(\mathrm{OH})$ vitamin $\mathrm{D}$ is influenced by vitamin $\mathrm{D}$ binding protein concentration and affinity and it varies in different clinical conditions. It may be affected by genetic, gender, hormones, ethnic and racial factors (33-39).

To assess the effect of cholecalciferol on PTH level; we noticed that previous studies included patients from different races. Our results suggest that Tunisian people may have lower DBP level and thus higher vitamin D bioavailability and greater PTH suppressing. This finding must be confirmed by genetic studies. It should be noted that the essential role of the kidney in producing the active form of vitamin D (1,25-hydroxy-vitamin D3 (1,25 (OH) D3) is an ancient concept. Dusso et al (39) confirmed that lalpha hydroxylase secretion is stimulated by $25(\mathrm{OH})$ vitamin $\mathrm{D}$ deficiency and can be produced by extra-renal sites. Additionally, 25(OH)vitamin D can be independent of calcitriol generation.

Indeed, many studies demonstrated that in vitro $25(\mathrm{OH})$ vitamin $\mathrm{D}$ can directly activate vitamin $\mathrm{D}$ receptor.

Otherwise, we noticed through this study that the response to cholecalciferol was better in vitamin D insufficiency group compared to vitamin D deficiency group. Therefore the more the deficit was accentuated the more difficult the correction is and we must supplement our patients earlier. In addition, $37.5 \%$ of our patients had excessive response with $25(\mathrm{OH})$ vitamin D levels $>60 \mathrm{ng} / \mathrm{mL}$ but we did not notice any toxicity mainly hypercalcemia for hyperphosphatemia. In fact, supplementation with cholecalciferol seems reasonable and well tolerated in HD patients if reasonable doses are used with regular monitoring.

\section{Conclusion}

In conclusion, our study is a Tunisian study regarding the prevalence of hypovitaminosis $\mathrm{D}$ in patients on $\mathrm{HD}$ and the effects of vitamin D supplementation on the serum level of $25(\mathrm{OH})$ vitamin $\mathrm{D}$, iPTH, calcium and phosphorus. In 
Table 4. Literature review

\begin{tabular}{|c|c|c|c|c|c|c|c|}
\hline Study & $\begin{array}{l}\text { No. of } \\
\text { patient }\end{array}$ & Mean Age (y) & $\begin{array}{l}\text { Initial value of } \\
25(\mathrm{OH}) \text { Vit D }\end{array}$ & $\begin{array}{c}\text { Initial value of } \\
\text { PTH }\end{array}$ & Treatment & $\begin{array}{l}\text { Study } \\
\text { duration }\end{array}$ & Results \\
\hline Jean et al & 107 & $66.4 \pm 15$ & $13 \pm 5 \mathrm{ng} / \mathrm{mL}$ & $\begin{array}{c}295(190-450) \\
\mathrm{pg} / \mathrm{mL}\end{array}$ & $\begin{array}{l}\text { Cholecalciferol } 100000 \\
\text { UI/month }\end{array}$ & 15 months & $\begin{array}{l}25(\mathrm{OH}) \text { vit } \mathrm{D} \text { after treatment } \\
42 \pm 11 \mathrm{mg} / \mathrm{mL} \\
\mathrm{Ca} \text {, phosphorus unchanged }\end{array}$ \\
\hline $\begin{array}{l}\text { Tokmak } \\
\text { et al }\end{array}$ & 64 & & $7 \pm 4 \mathrm{ng} / \mathrm{mL}$ & $217 \pm 217 \mathrm{pg} / \mathrm{mL}$ & $\begin{array}{l}\text { Cholecalciferol } \\
20000 \text { UI/week }\end{array}$ & 9 month & $\begin{array}{l}25(\mathrm{OH}) \text { vit } \mathrm{D} \text { after treatment } \\
32 \pm 11 \mathrm{ng} / \mathrm{mL} \\
\mathrm{Ca} 2.28 \pm 0.17 \text { to } 2.37 \pm 0.19 \\
\mathrm{mmol} / \mathrm{PTH}\end{array}$ \\
\hline $\begin{array}{l}\text { Matias } \\
\text { et al. }\end{array}$ & 158 & $62.8 \pm 14.8$ & $22 \pm 12 \mathrm{ng} / \mathrm{mL}$ & $233 \mathrm{pg} / \mathrm{mL}$ & $\begin{array}{l}\text { Cholecalciferol } 50000 \text { UI per } \\
\text { week if } 25(\mathrm{OH}) \text { vit } \mathrm{D}<15 \\
\mathrm{pg} / \mathrm{mL} \\
10000 \text { UI per week if } 25(\mathrm{OH}) \\
\text { vit } \mathrm{D} \text { between } 16 \text { and } 30 \\
\mathrm{pg} / \mathrm{mL} \\
2700 \text { UI } 3 \text { times a week if } \\
25(\mathrm{OH}) \text { vit } \mathrm{D}>30 \mathrm{pg} / \mathrm{mL}\end{array}$ & 1 year & $\begin{array}{l}25(\mathrm{OH}) \text { vit } \mathrm{D} \text { after treatment } \\
42 \pm 12 \mathrm{pg} / \mathrm{mL} \\
\mathrm{Ca} \text { from } 8.6 \pm 0.8 \text { to } 8.4 \pm 0.7 \\
\mathrm{mg} / \mathrm{dL} \\
\mathrm{Ph} \text { from } 4.7 \pm 1.3 \text { to } 4.5 \pm 1.3 \\
\mathrm{mg} / \mathrm{dL} \\
\mathrm{PTH} 233 \text { to } 200 \mathrm{pg} / \mathrm{mL}\end{array}$ \\
\hline $\begin{array}{l}\text { Jakopin } \\
\text { et al }\end{array}$ & 101 & $63.3 \pm 13.5$ & $12 \pm 7 \mathrm{ng} / \mathrm{mL}$ & $\begin{array}{c}307.3 \pm 236.9 \\
\mathrm{pg} / \mathrm{mL}\end{array}$ & $\begin{array}{l}\text { Cholecalciferol } 40000 \mathrm{UI} / \\
\text { month for } 3 \text { months to repeat } \\
\text { if deficit persists }\end{array}$ & 2 years & $\begin{array}{l}25(\mathrm{OH}) \text { vit D after treatment } \\
22 \pm 6 \mathrm{ng} / \mathrm{mL} \\
\mathrm{Ca} \text { from } 2.28 \pm 0.14 \text { to } 2.16 \pm 0.17 \\
\mathrm{mmol} / \mathrm{L} \\
\text { Ph and PTH unchanged }\end{array}$ \\
\hline $\begin{array}{l}\text { Bucharles } \\
\text { et al }\end{array}$ & 30 & $59 \pm 15$ & $18.1 \pm 6.6 \mathrm{ng} / \mathrm{mL}$ & $165 \pm 80 \mathrm{pg} / \mathrm{mL}$ & $\begin{array}{l}\text { Cholecalciferol } 50000 \text { UI/ } \\
\text { week for } 12 \text { weeks } \\
20000 \text { UI/week }\end{array}$ & 6 months & $\begin{array}{l}25(\mathrm{OH}) \text { vit } \mathrm{D} \text { after treatment } \\
40 \pm 10 \mathrm{mg} / \mathrm{ml} \\
\mathrm{Ph} \text { and } \mathrm{PTH} \text { unchanged }\end{array}$ \\
\hline Our study & 43 & 51.3 & $\begin{array}{c}17.89(6-57.3) \\
\mathrm{ng} / \mathrm{mL}\end{array}$ & $956 \pm 413.24$ & $\begin{array}{l}\text { Cholecalciferol } 200000 \mathrm{UI} \\
\text { (M1-M2-M4-M6) }\end{array}$ & 6 months & $\begin{array}{l}\text { 25(OH) vit D after treatment } \\
51.8 . \text { PTH from } 956 \text { to } 699 \mathrm{pg} / \\
\mathrm{mL} \\
\text { Ca from } 2.05 \text { to } 2.15 \mathrm{mmol} / \mathrm{L}\end{array}$ \\
\hline
\end{tabular}

Tunisia, studies regarding hypovitaminosis $\mathrm{D}$ in patients with CKD stage 5 on dialysis are not numerous and we do not have protocols of supplementation with native vitamin D. In fact, most centers are used to using only active vitamin $\mathrm{D}$ in $\mathrm{HD}$ patients.

The interpretation of the results of this study is limited by the relatively low number of patients and by the absence of a control group.

With the KDIGO recommendation being recently released, it is hypothesized that Tunisian nephrologists will implement a strategy for $25(\mathrm{OH})$ vitamin D deficiency checking and supplementation by native vitamin $\mathrm{D}$ more systematically.

This is a Tunisian study regarding the prevalence of hypovitaminosis $\mathrm{D}$ in patients on $\mathrm{HD}$ and the effects of vitamin D supplementation on the serum level of iPTH, calcium and phosphorus. However, vitamin D deficiency appears to be widely used in Tunisian HD people and we must have a national protocol. The supplementation with cholecalciferol seems reasonable and well tolerated in HD patients if reasonable doses are used with regular monitoring to prevent the development of toxicity, mainly hypercalcemia and hyperphosphatemia.

Many unanswered questions still exist; is there long-term toxicity associated with maintaining high serum $25(\mathrm{OH})$ vitamin D levels? Which is the best frequency of vitamin $\mathrm{D}$ administration; monthly weekly or daily? What is the optimal serum $25(\mathrm{OH})$ vitamin $\mathrm{D}$ target level according to the severity of secondary hyperparathyroidism?

Other controlled studies are needed to answer these questions and must be based on hard criteria such as the risk of low bone remodeling, skeletal fractures and mortality.

\section{Limitations of the study}

The most important was the relatively small number of patients.

\section{Authors' contribution}

All authors contributed equally to the manuscript.

\section{Conflicts of interest}

The authors declare no conflicts of interest.

\section{Ethical considerations}

Ethical issues (including plagiarism, data fabrication, double publication) have been completely observed by the authors. All patients gave written informed consent.

\section{Funding/support}

There was no support/funding.

\section{References}

1. Franca Gois PH, Wolley M, Ranganathan D, Seguro AC. Vitamin D Deficiency in chronic kidney disease: recent evidence and controversies. Int J Environ Res Public HealtH. 2018;15:1773. doi: 10.3390/ijerph15081773.

2. López-Ramiro E, Rubert M, Mahillo I, de la Piedra C. Secondary hyperparathyroidism due to vitamin D deficiency. Rev 
Osteoporos Metab Miner. 2016;8: 5-60

3. Vitamin D Therapy In CKD Patients. NKF KDOQI Guideline. National Kidney Foundation .2003

4. Townsend K, Evans KN, Campbell MJ, Colston KW, Adams JS, Hewison M. Biological actions of extra-renal 25-hydroxyvitamin D-1alpha-hydroxylase and implications for chemoprevention and treatment. J Steroid Biochem Mol Biol. 2005;97:103-9. doi: 10.1016/j.jsbmb.2005.06.004.

5. Kidney Disease: Improving Global Outcomes (KDIGO) CKDMBD Update Work Group. KDIGO 2017 Clinical Practice Guideline Update for the Diagnosis, Evaluation, Prevention, and Treatment of Chronic Kidney Disease-Mineral and Bone Disorder (CKD-MBD). Kidney Int Suppl (2011). 2017;7:1-59.

6. Eknoyan G, Levin A, Levin NW., Bone metabolism and disease in chronic kidney disease. Am J Kidney Dis. 2003;42:1-201. doi:10.1016/S0272-6386(03)00905-3

7. Dusso AS. Kidney disease and vitamin D levels: 25-hydroxyvitamin D, 1,25-dihydroxyvitamin D, and VDR activation. Kidney Int Suppl. 2011;1:136-41.

8. Zehnder D. Extrarenal Expression of 25-Hydroxyvitamin D3-1aHydroxylase. J Clin Endocrinol Metab. 2001;86:888-94.

9. Giannini S, Mazzaferro S, Minisola S, De Nicola L, Rossini M, Cozzolino M. Raising awareness on the therapeutic role of cholecalciferol in CKD: a multidisciplinary-based opinion. Endocrine. 2018;59:242-59. doi: 10.1007/s12020-017-1369-3.

10. Kalantar-Zadeh K, Kovesdy CP. Clinical outcomes with active versus nutritional vitamin $\mathrm{D}$ compounds in chronic kidney disease. Clin J Am Soc Nephrol. 2009;4:1529-39.

11. Matias PJ, Jorge C, Ferreira C, Borges M, Aires I, Amaral T, et al. Cholecalciferol supplementation in hemodialysis patients: effects on mineral metabolism, inflammation, and cardiac dimension parameters. Clin J Am Soc Nephrol. 2010;5:905-11.

12. Drechsler C, Pilz S, Obermayer-Pietsch B, Verduijn M, Tomaschitz A, Krane $\mathrm{V}$, et al. Vitamin D deficiency is associated with sudden cardiac death, combined cardiovascular events, and mortality in haemodialysis patients. Eur Heart J. 2010;31:2253-61.

13. Boer $\mathrm{IH}$. Vitamin D and glucose metabolism in chronic kidney disease. Curr Opin Nephrol Hypertens. 2008;1 7:566-72.

14. Hashemipour S, Larijani B, Adibi H, Javadi E, Sedaghat M, Pajouhi $M$, et al. Vitamin D deficiency and causative factors in the population of Tehran. BMC Public Health. 2004;4:38.

15. Jean G, Lataillade D, Genet L, Legrand E, Kuentz F, MoreauGaudry X, et al. Impact of hypovitaminosis D and alfacalcidol therapy on survival of hemodialysis patients: results from the French ARNOS study. Nephron Clin Pract. 2011;118:c204-210.

16. Sanusi AA, Arogundade FA, Oladigbo M, Ogini LM, Akinsola A. Prevalence and pattern of renal bone disease in end stage renal disease patients in Ile-Ife, Nigeria. West African Journal of Medicine.2010;29(2)

17. Meddeb N, Sahli H, Chahed M, Abdelmoula J, Feki M, Salah $\mathrm{H}$, et al. Vitamin D deficiency in Tunisia. Osteoporos Int. 2005;16:180-3. doi: 10.1007/s00198-004-1658-6.

18. Mahfoudh H, Agrebi I, Toumi S, Matallah S, Yaich S, Kammoun $\mathrm{K}$, et al. Déficit en calcidiol (25 OH vitamine D) chez les dialysés du CHU de Sfax (sud tunisien). Néphrologie \& Thérapeutique . 2012;8:296-337.

19. Pike JW, Christakos S. Biology and Mechanisms of Action of the Vitamin D Hormone. Endocrinol Metab Clin North Am. 2017;46:815-43.

20. Young MRI, Xiong Y. Influence of vitamin D on cancer risk and treatment: Why the variability? Trends Cancer Res. 2018;13:4353.

21. Wang H, Chen W, Li D, Yin X, Zhang X, Olsen N, et al. Vitamin D and Chronic Diseases. Aging Dis. 2017;8:346-53.

22. Bischoff-Ferrari HA. Optimal serum 25-hydroxyvitamin D levels for multiple health outcomes. Adv Exp Med Biol. 2008;624:5571.

23. Jacob Al, Sallman A, Santiz Z, Hollis BW. Defective photoproduction of cholecalciferol in normal and uremic humans. J Nutr. 1984;114:1313-9.

24. Michaud J, Naud J, Ouimet D, Demers C, Petit J-L, Leblond FA, et al. Reduced Hepatic Synthesis of Calcidiol in Uremia. J Am Soc Nephrol. 2010;21:1488-97.

25. Kovesdy CP, Kalantar-Zadeh K. Vitamin D receptor activation and survival in chronic kidney disease. Kidney Int. 2008;73:135563.

26. Zellama D, Fradi M, Azzabi A, Belarbia A, Guedri Y, Mrabet $\mathrm{S}$, et al. Évaluation des troubles du métabolisme minéral et osseux dans une population de patients hémodialysés, selon les recommandations des KDIGO et KDOQI. Néphrologie \& Thérapeutique 2011;7:301-43.

27. Tripkovic L, Lambert H, Hart K, Smith CP, Bucca G, Penson S, et al. Comparison of vitamin D2 and vitamin D3 supplementation in raising serum 25-hydroxyvitamin D status: a systematic review and meta-analysis123. Am J Clin Nutr. 2012;95:1357-64.

28. Matias PJ, Ferreira C, Jorge C, Borges M, Aires I, Amaral $\mathrm{T}$, et al. 25-Hydroxyvitamin D3, arterial calcifications and cardiovascular risk markers in haemodialysis patients. Nephrol Dial Transplant. 2009;24:611-8.

29. Delanaye P, Weekers L, Warling X, Moonen M, Smelten N, Médart $\mathrm{L}$, et al. Cholecalciferol in haemodialysis patients: a randomized, double-blind, proof-of-concept and safety study. Nephrol Dial Transplant. 2013;28:1779-86.

30. Dammak N, Chaabouni Y, Kammoun F, Charfi A, Bouhamed L, Azaiz A, et al. La supplémentation en vitamine D chez les hémodialysés: essai clinique croisé comparant le cholécalciférol D3 et l'ergocalciférol D. Néphrologie \& Thérapeutique. 2018; $14: 320$

31. Tokmak F, Quack I, Schieren G, Sellin L, Rattensperger D, Holland-Letz T, et al. High-dose cholecalciferol to correct vitamin D deficiency in haemodialysis patients. Nephrol Dial Transplant. 2008;23:4016-20.

32. Jakopin E, Pecovnik Balon B, Ekart R, Gorenjak M. High-dose cholecalciferol supplementation for vitamin $D$ deficiency in haemodialysis patients. J Int Med Res. 2011;39:1099-106.

33. Bucharles S, Barberato SH, Stinghen AEM, Gruber B, Piekala $\mathrm{L}$, Dambiski AC, et al. Impact of cholecalciferol treatment on biomarkers of inflammation and myocardial structure in hemodialysis patients without hyperparathyroidism. J Ren Nutr. 2012;22:284-91.

34. Armas LAG, Zena M, Lund R, Heaney RP. Calcium absorption response to cholecalciferol supplementation in hemodialysis. Clin J Am Soc Nephrol. 2013;8:1003-8.

35. Descombes E, Fellay B, Hemett OM, Magnin J-L, Fellay G. Oral postdialysis cholecalciferol supplementation in patients on maintenance hemodialysis: a dose-response approach. Int J Nephrol. 2014;2014:597429.

36. Wasse H, Huang R, Long Q, Singapuri S, Raggi P, Tangpricha V. Efficacy and safety of a short course of very-high-dose cholecalciferol in hemodialysis. Am J Clin Nutr. 2012;95:522-8.

37. Li C, Chen P, Duan X, Wang J, Shu B, Li X, et al. Bioavailable 25(OH)D but Not Total 25(OH)D Is an Independent Determinant for Bone Mineral Density in Chinese Postmenopausal Women. EBioMedicine. 2016;15:184-92. doi: 10.1016/j. ebiom.2016.11.029

38. Mazahery H, von Hurst PR. Factors Affecting 25-Hydroxyvitamin D Concentration in Response to Vitamin D Supplementation. Nutrients. 2015;7:5111-42.

39. Dusso AS, Brown AJ, Slatopolsky E. Vitamin D. Am J Physio Renal Physiol. 2005;289:F8-28. 